\title{
The participation of plant cell organelles in compatible and incompatible potato virus Y-tobacco and -potato plant interaction
}

\author{
Katarzyna Otulak · Grażyna Garbaczewska
}

Received: 17 May 2013/Revised: 27 August 2013/Accepted: 9 September 2013/Published online: 29 September 2013

(C) The Author(s) 2013. This article is published with open access at Springerlink.com

\begin{abstract}
Potyviruses replicate and express their genomes in the cytoplasm in closely related membranous structures such as the endoplasmic reticulum or in the vicinity of the ER. The present research demonstrates the participation of plant cell organelles based on ultrastructural examination of compatible and incompatible interactions in tobacco- and potato-potato virus Y (PVY) necrotic strains. In two interaction types, $\mathrm{PVY}^{\mathrm{N}} \mathrm{Wi}$ and $\mathrm{PVY}^{\mathrm{NTN}}$ particles were documented inside cell nuclei. Virus cytoplasmic inclusions and particles were associated with nuclear envelope pore complexes. Moreover, the PVY capsid protein was immunolocalised in the cell nucleus and nucleolus. Our results for the first time show PVY particles and capsid proteins inside the mitochondrion in compatible interactions, whereas in hypersensitive responses these interactions were identified inside chloroplasts. The PVY particles attached to mitochondria caused association groups of these organelles. The ultrastructural analysis clearly demonstrated both the dynamics of the endoplasmatic reticulum in two types of PVY interactions and connections between PVY cytoplasmic inclusions and particles with its membranous structures. Moreover, we demonstrated strongly localised immunodetection of the PVY capsid protein on the surface and in the vicinity of ER in cases of hypersensitive response as well as in compatible interaction.
\end{abstract}

Communicated by B. Barna.

K. Otulak $(\bowtie) \cdot$ G. Garbaczewska

Department of Botany, Faculty of Agriculture and Biology,

Warsaw University of Life Sciences, SGGW,

Nowoursynowska 159, 02-776 Warsaw, Poland

e-mail: katarzyna_otulak@sggw.pl
Keywords Endoplasmic reticulum · Hypersensitive response - Mitochondria - Nucleus - Potato virus Y . Ultrastructure

\section{Introduction}

Potato virus Y (PVY), a member of the Potyviridae, is a filamentous virus possessing (+)ss RNA (Fauquet et al. 2005). It is one of the most common viruses infecting a wide range of plant species, especially Solanaceous plants (Robert et al. 2000). PVY is rapidly becoming the most economically important potato virus and causes severe yield losses (10-80\%) to potato growers in all potato growing regions in the world (Valkonen 2007). Isolates belonging to the $\mathrm{PVY}^{\mathrm{N}}$ group induce veinal necrotic leaves on potato. Variants of PVY have been described in Poland-PVY ${ }^{\mathrm{N}}$ W isolates (Chrzanowska 1991) and Hungary-PVY ${ }^{\mathrm{NTN}}$ (Beczner et al. 1984). PVY ${ }^{\mathrm{NTN}}$ isolates have all the biological characteristics of the $\mathrm{PVY}^{\mathrm{N}}$ group and are distinguished from standard $\mathrm{PVY}^{\mathrm{N}}$ isolates by their ability to induce necrosis on potato tubers (potato tuber necrosis ringspot disease, PTNRD).

Plants reacting to virus infection reveal a broad spectrum of physiological changes which are elicited by pathological changes on the ultrastructural level. The host cell functional machinery is hijacked by the virus for the biosynthesis of the first set of viral proteins, the subcellular location of virus replication and at least its mechanism of transport. The potyviral RNA genome encodes one polyprotein precursor that is cleaved by cis and trans catalysis into 11 mature proteins, by three virus coded proteases (Chung et al. 2008; Urcuqui-Inchima et al. 2001). The replication of potyviruses occurs in the cytoplasm of infected cells, but it is closely associated with unique virus- 
induced intracellular membranous structures (Kopek et al. 2007). It has been suggested that these membranous structures or vesicles provide a scaffold for anchoring the virus replication complex. The process of RNA replication could be confined to a specific "safeguarded" cytoplasm compartment, preventing the activation of certain host defence mechanisms, as was first proposed on the example of TMV (Riedel et al. 1998). If cellular organelles such as lysosomes, chloroplast, peroxisomes, endosomes are suggested to be the replication site for the tymovirus and tombusvirus, it is possible that potyviruses do not only exploit the endoplasmatic reticulum (McCartney et al. 2005; Prod'homme et al. 2001). Most of the data used to understand host responses to potyviruses have been obtained from biochemical and physiological aspects of investigations, rather than from single cells and organelles. It has been revealed that different plant viruses affect photosynthesis (Balachandran et al. 1997; Rahoutei et al. 2000). There have been potyviral infection reports of photosynthetic rates influenced by concentrations of soluble sugars and increased respiration rates (Lohaus et al. 2000; Shalitin and Wolf 2000). Ultrastructural effects include PVY necrotic strains-Solanaceous plant cell organelle interactions are very poor and reports have concentrated on documentation of potyvirus cytoplasmic inclusions, changes in size and numbers of organelles (especially chloroplast). The aim of the present paper is an ultrastructural one, with the goal of indicating the participation of plant cell organelles in two types of PVY-tobacco and PVY-potato interactions:-compatible interactions between PVY necrotic strains and tobacco or potato susceptible cultivars;-incompatible interactions (hypersensitive response) between PVY necrotic strains and the potato cultivar Rywal with the $N y-1$ hypersensitive gene (Szajko et al. 2008). Such data are needed for a more precise characterisation and localisation of PVY modifications within host cells and organelles in different types of interactions.

\section{Materials and methods}

\section{Plant material and PVY strains}

Solanum tuberosum cv. Igor, cv. Rywal and Nicotiana tabacum cv. Samsun plants were grown in phytotron conditions (a growth chamber), at a temperature of $18{ }^{\circ} \mathrm{C}$, with 16-h light of intensity $400 \mu \mathrm{mol} \mathrm{m} \mathrm{m}^{-2} \mathrm{~s}^{-1}$ photosynthetically active radiation (PAR). Plants with four levels of leaves were infected with two necrotic strains of PVY: PVY $^{\mathrm{N}}$ Wi or PVY ${ }^{\mathrm{NTN}}$ (Chrzanowska 1991, 1994). For 3 years, three times per year, ten plants were inoculated with PVY suspension mechanically using carborundum.
The suspension of sap from PVY infected tissue in $0.1 \mathrm{M}$ phosphate buffer ( $\mathrm{pH}$ 7.4) obtained from tobacco cv. Samsun leaf blades 15 days after inoculation (one infected, mortar grinded leaf in $10 \mathrm{ml}$ phosphate buffer). Plants were inoculated with 15 drops of sap from infected tissues (one drop $50 \mu \mathrm{l})$. Control plant material was inoculated with phosphate buffer.

Both, tobacco cv. Samsun plants used as inoculum and infected plants were tested at IHAR Młochów (Poland) using the DAS-ELISA procedure (according to Clark and Adams 1977). Material was harvested 15 and 30 days after $\mathrm{PVY}^{\mathrm{N}} \mathrm{Wi}$ or PVY ${ }^{\mathrm{NTN}}$ inoculation for compatible interaction, and from $10 \mathrm{~h}$ to 24 days after $\mathrm{PVY}^{\mathrm{N}} \mathrm{Wi}$ or $\mathrm{PVY}^{\mathrm{NTN}}$ inoculation for (incompatible) hypersensitive response. Light sprouts were obtained from potato cv. Igor infected tubers. Tissue samples were taken from five plants of a given variety of leaves directly infected and non-infected, as well as from necrosis and the area around necrosis.

Ultrastructural analysis in transmission electron microscopy

The samples were fixed in $2 \%(\mathrm{w} / \mathrm{v})$ paraformaldehyde and $2 \%(\mathrm{v} / \mathrm{v})$ glutaraldehyde in $0.05 \mathrm{M}$ cacodylate buffer ( $\mathrm{pH}$ 7.2-7.4) (Karnovsky 1965) for $2 \mathrm{~h}$ at room temperature. Then, the samples were contrasted and fixed in $2 \%$ (w/v) $\mathrm{OsO}_{4}$ in cacodylate buffer for $2 \mathrm{~h}$ at $4{ }^{\circ} \mathrm{C}$. The sections were rinsed with sodium cacodylate and then dehydrated in a series of increasingly strong water solutions of ethanol. The samples were gradually saturated with Epon 812 (Fluka) resin and polymerised for $24 \mathrm{~h}$ at $60{ }^{\circ} \mathrm{C}$.

Observations were conducted in a Morgagni 268D transmission electron microscope (FEI, The Netherlands). Photographic documentation was prepared with the use of a "Morada" digital camera (SIS) and the iTEM computer programme.

\section{Immunolocalisation of the PVY capsid protein}

Immunolocalisation of the PVY capsid protein in potato and tobacco tissues infected with PVY ${ }^{\text {NTN }}$ was performed according to the van Lent and Verudin method (1986). For localisation we used primary mouse monoclonal antibodies directed at the C-terminus of the PVY capsid protein, specific for necrotic PVY strains (BIOREBA AG), according to Kerlan and Le Romancer (1992) and Chrzanowska and Doroszewska (1997). The specificity of the interaction between antibodies and viral suspension was tested by DAS-ELISA test measuring extinction with a wavelength of $405 \mathrm{~nm}$. Ultrathin tissue sections were treated with $10 \%$ solution of hydrogen peroxide for $10 \mathrm{~min}$ in order to remove epoxide resin. The sections were incubated for $15 \mathrm{~min}$ in blocking buffer, which included 
NGS (ICN) in $0.05 \mathrm{M}$ buffer Tris- $\mathrm{HCl}$ pH 7.6 with $0.1 \%$ $\mathrm{BSA}$, at a ratio of 1:30. Then, they were rinsed three times in TBS-Tween 20 buffer for $10 \mathrm{~min}$ and incubated for $1 \mathrm{~h}$ with primary mouse antibody anti CP-PVY 1:50 in TBSTween 20 buffer, $\mathrm{pH}$ 8.2. Then, the sections were rinsed in $0.02 \mathrm{M}$ Tris- $\mathrm{HCl}$ buffer with $0.1 \% \mathrm{BSA}$ and $0.05 \%$ Tween 20, pH 8.2. Subsequently, the samples were treated for $1 \mathrm{~h}$ with secondary anti-mouse antibody $\operatorname{IgG} 1: 30$ conjugated with colloidal gold $(5 \mathrm{~nm})$. As previously, the sections were rinsed firstly in buffer, then in distilled water, $2 \times 5 \mathrm{~min}$. The sections were contrasted with $2 \%$ uranyl acetate solution for $7 \mathrm{~min}$ and rinsed with distilled water, $5 \times 2 \mathrm{~min}$.

Observations were conducted in a Morgagni 268D transmission electron microscope (FEI, The Netherlands). Photographic documentation was prepared with the use of a "Morada" digital camera (SIS) and the iTEM computer programme.

\section{Results}

An ultrastructural analysis of tobacco and potato tissues in compatible interaction and hypersensitive response with PVY necrotic strains demonstrated strong changes in plant cell organelles and their engagement in viral infection development. The presence of all types of inclusions and virus particles in all tissue types was demonstrated 15 days after inoculation in the case of PVY-tobacco cv. Samsun or PVY-potato cv. Igor compatible interaction (Otulak and Garbaczewska 2012) at the moment of PVY infection symptoms occurrence. In compatible PVY necrotic strainstobacco or -potato interaction plants revealed systemic necroses and leaf chlorosis 15 days after inoculation (Fig. 1a). Starting from 5 days after inoculation yellow blemishes between veins could also be noticed. Control plant material, inoculated only with phosphate buffer didn't reveal infection symptoms (Fig. 1b, d). In PVY necrotic strains-potato cv. Rywal interaction it observed necrosis restricted only to inoculated leaflets starting from 3 days after inoculation (Fig. 1c). In PVY-potato cv. Rywal hypersensitive response, virus particles were observed starting from $10 \mathrm{~h}$ after inoculation, while the presence of viral cytoplasmic inclusions was demonstrated $24 \mathrm{~h}$ after $\mathrm{PVY}^{\mathrm{NTN}}$ or $\mathrm{PVY}^{\mathrm{N}} \mathrm{Wi}$ inoculation, despite the fact that symptoms occurred 3 days after inoculation (Otulak and Garbaczewska 2010). The results of both types of interactions were dynamic changes in cell organelles ultrastructure of the host plants. Our HR ultrastructural analyses concentrated on plants material from inoculated leaves, because tissues from noninoculated leaves didn't reveal significant, dynamic changes of potato organelles. Despite hypersensitive reaction, we noticed PVY particles outside inoculated leaves in mesophyll and both vascular tissues. This process was asymptomatic and virus particles frequency was a lot lower than in a leaf that was inoculated mechanically.

The changes in cell nucleus structure were observed as an effect of infection with PVY necrotic strains compared to healthy plants tissues (Fig. 2c, d). Lobed (amoeboid) shape of the nucleus was documented in the cells of palisade parenchyma or spongy parenchyma, especially when virus particles and inclusion were present on the cytoplasm area (Figs. 2a, 3b). Frequent phenomenon, especially in hypersensitive reactions, was an increase in nuclear pore complexes diameter, also attached to virus particles (Fig. 3a). Moreover, a dilatation of nuclear envelope causing formation of perinuclear areas filled with fibrillar substance was observed (Fig. 3c). While rapid necrotic changes accompanying HR were observed in the tissues, cytopathological changes in cell nucleus in mesophyll, phloem and xylem involved chromatic condensation (Fig. 3d), or vesicles disconnection from nuclear envelope (Fig. 3a, c). The presence of virus particles inside the cell nucleus was noted both in compatible interaction of tobacco and potato plants with PVY and in HR (Fig. 4a-c). This situation was noted especially when considerable amounts of virus particles and/or PVY cytoplasmic inclusions were deposited in the cells. Immunolocalisation of capsid protein of $\mathrm{PVY}^{\mathrm{NTN}}$ virus demonstrated colloidal gold particles proving the presence of epitopes of 15-amino acid sequence of PVY ${ }^{\mathrm{NTN}}$ capsid protein inside the cell nucleus in karyolymph, as well as on nucleolus area (Fig. 9c).

The mitochondria are subject to considerable changes resulting from compatible and incompatible interaction of PVY-potato or -tobacco necrotic strains. An ultrastructural analysis of all types of infected tissues allowed to note an increase in these organelle number (Figs. 2b, 5b) compared to healthy plants (Fig. 2d). PVY ${ }^{\mathrm{N}} \mathrm{Wi}$ or PVY ${ }^{\mathrm{NTN}}$ particles attached to mitochondrial envelope were observed in infected tissues both of tobacco and potato (Figs. 2b, 5a). There organelles are associated with the particles forming sometimes clusters of a few mitochondria associations (Fig. 5a). Formation of electron-lucent areas was noted inside mitochondria during mitochondrial cristae swelling in necrosis subjected tissues (Fig. 5b). Also formation of mitochondrial exosomes was noted; such enlargement of mitochondrial cristae was typical especially for a rapid response on an infection, i.e. HR (1 dai) (Fig. 5c). This kind of changes was often observed where the research material was potato cv. Igor light sprouts (Fig. 5d). The presence of $\mathrm{PVY}^{\mathrm{N}} \mathrm{Wi}$ or PVY ${ }^{\mathrm{NTN}}$ particles was demonstrated during a compatible interaction not only around but also inside mitochondria (Fig. 6a, b) causing unnatural elongation of these organelle. Immunolocalisation of 


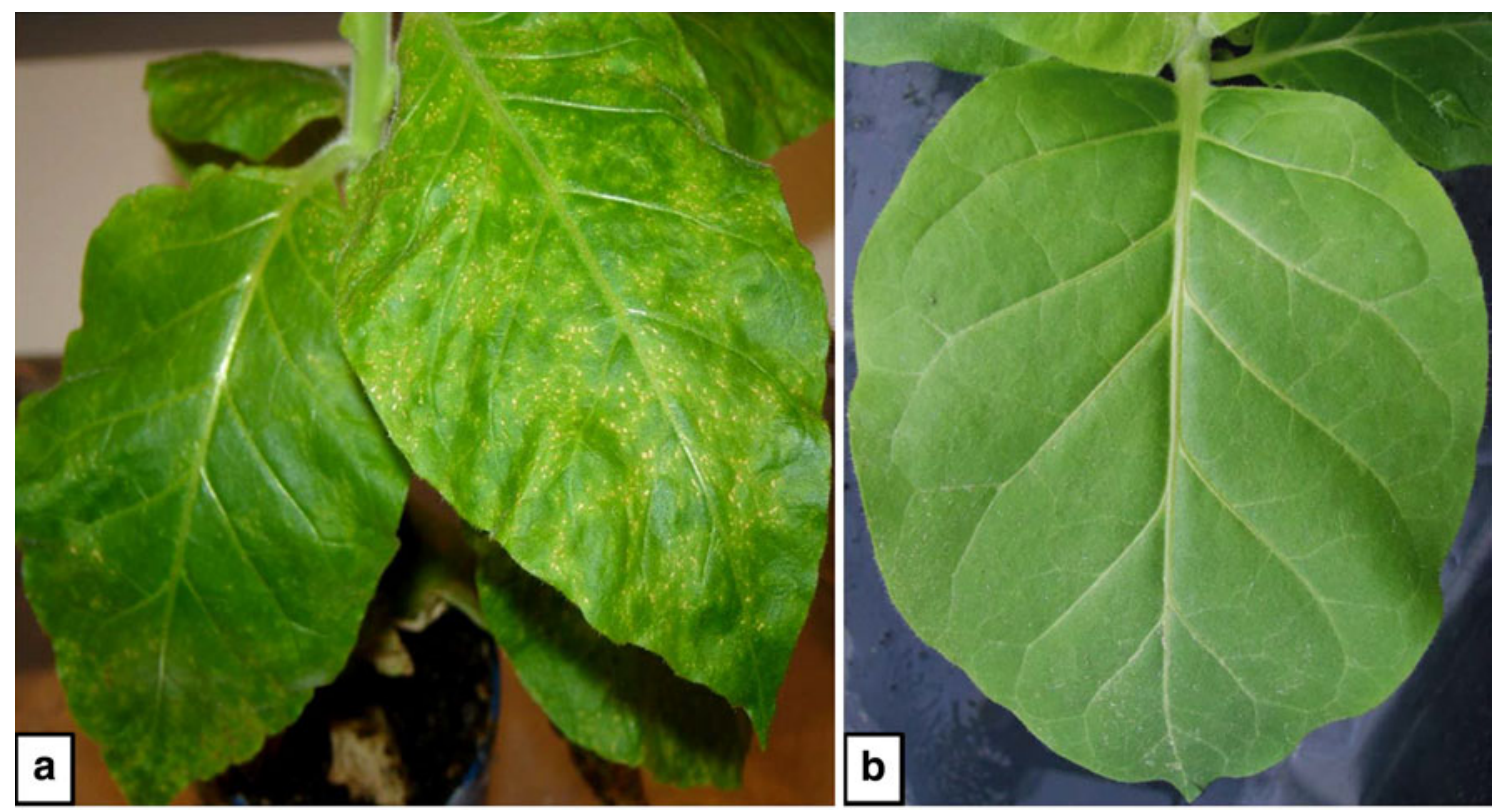

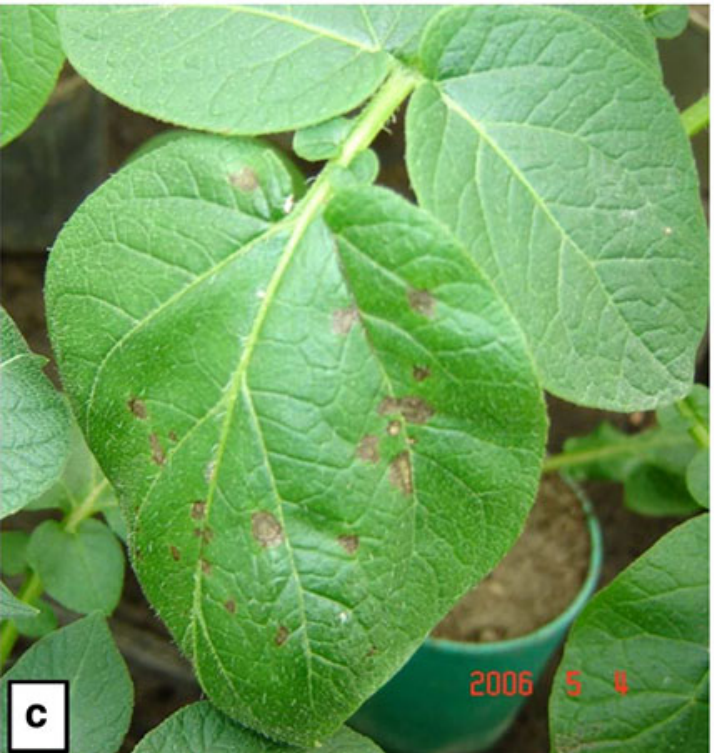

Fig. 1 Symptoms of compatible and incompatible tobacco- or potato-PVY necrotic strains reaction. a Tobacco cv. Samsun leaf 15 days after PVY NTN inoculation. Systemic necrotic reaction with yellowing blemishes as a results compatible interaction, b healthy

PVY ${ }^{\mathrm{NTN}}$ capsid protein demonstrated the presence of colloidal gold particles inside mitochondria 15, 30 days after inoculation in the case of compatible interaction, and 3 days after hypersensitive response (Fig. 9a, c).

Organelles engaged in interaction of necrotic PVY strains in host plants cells included plastids, especially chloroplasts. Disorders in chloroplast lamellas, shape changes and deformations of these organelles which may have proved leaf blades chlorosis were observed in necrotic cells both in compatible and incompatible interactions (Figs. 7a, 8a). Virus particles of PVY necrotic strains were

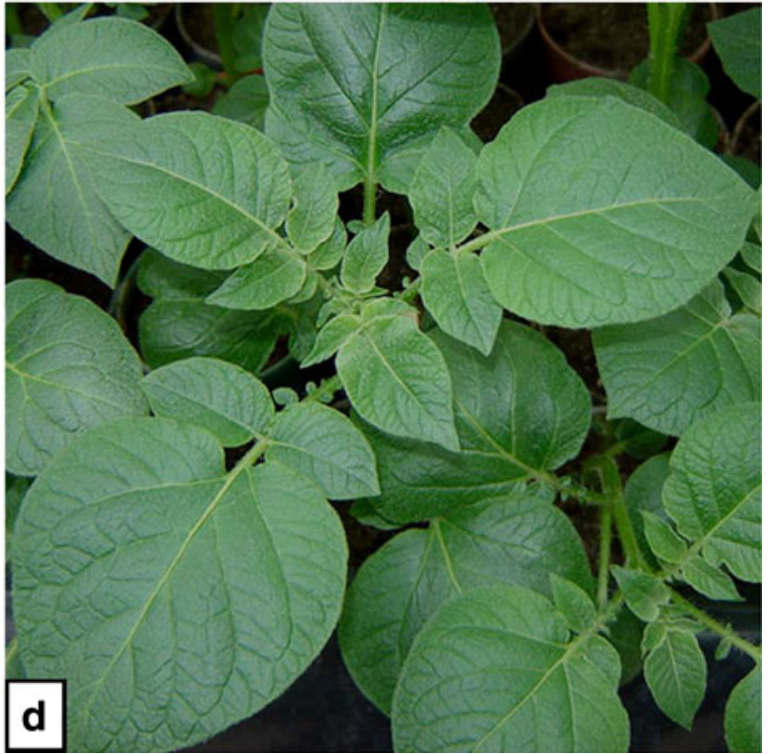

tobacco leaflets, control material, $\mathbf{c}$ potato cv. Rywal 3 days after PVY NTN infection. Necrotic reaction restricted to the inoculation areas as a result hypersensitive response and $\mathbf{d}$ healthy potato plants, control material

attached to chloroplast envelope just 1 day after inoculation in HR; sometimes the particles linked the adjacent organelles (Fig. 8b, c). In turn, chloroplast distinctly deprived of envelope was often observed as soon as 1 day after inoculation in a direct contact with particles or in their vicinity (Figs. 7c, 8a). The presence of virus particles inside chloroplasts of usually deformed shape resulting from virus particles presence was noted in HR 5 days after inoculation (Fig. 6c, d). Despite an occurrence of PVY particles inside the chloroplasts, PVY CP immunolocalisation did not demonstrate the presence of this viral protein 
Fig. 2 Ultrastructure of the tobacco and potato mesophyll cells after infection with $\mathrm{PVY}^{\mathrm{NTN}}$ or $\mathrm{PVY}^{\mathrm{N}} \mathrm{Wi}$. a Fragment of palisade parenchyma (Pme) of the mesophyll of potato cv. Igor after infection with PVY ${ }^{\text {NTN }}$. In cytoplasm the following are present: lobed, amoeboid nucleus $(N)$ structure, virus particles $(V P)$ and cytoplasmic inclusions $(C I)$, bar $=2.5 \mu \mathrm{m}$, b spongy parenchyma (Sme) after infection with $\mathrm{PVY}^{\mathrm{N}}$ Wi. Cytoplasmic inclusions in cytoplasm $(C I)$. Particles of $\mathrm{PVY}^{\mathrm{N}} \mathrm{Wi}(V P)$ attached to mitochondria envelope (arrows), bar $=0.1 \mu \mathrm{m}$, c fragment of healthy potato cv. Igor phloem parenchyma cells, bar $=2 \mu \mathrm{m}$ and $\mathbf{d}$ healthy tobacco cv. Samsun palisade mesophyll cells, bar $=0.1 \mu \mathrm{m}$

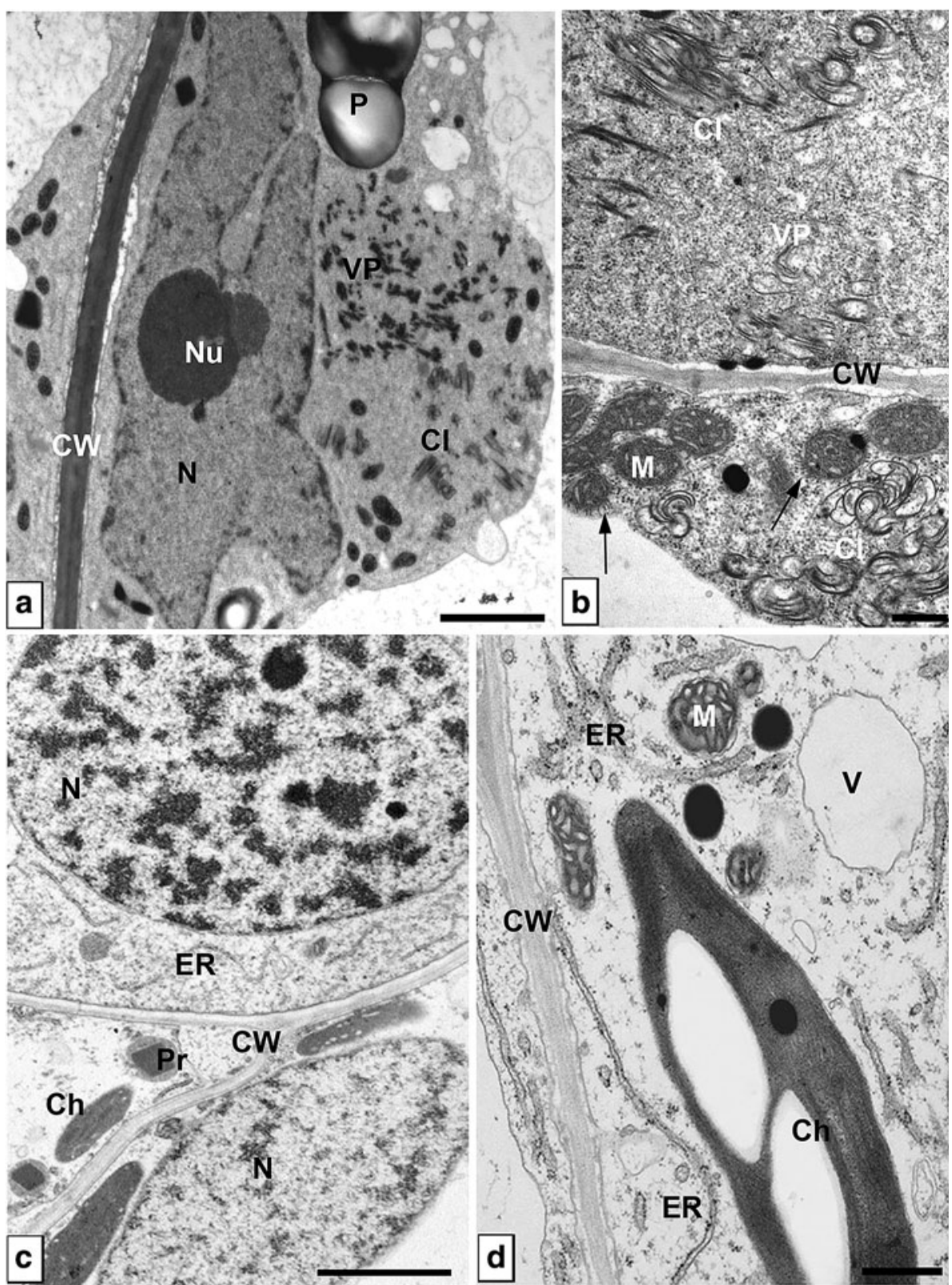

in chloroplast stroma. Colloidal gold particles were usually deposited around this organelle in cytoplasm, especially in the site where PVY particles were present (Fig. 9b). The observations concerning light sprouts allowed determining a disorganisation in amyloplast structure involving disruption of plastid surrounding membrane and their stoma connection to cytoplasm. Numerous virus inclusions or particles were usually observed in direct vicinity, in storage parenchyma cytoplasm (Fig. 7b).

High activity of endoplasmic reticulum was noted in hypersensitive response and compatible interaction in mesophyll and vascular tissues. The particles of $\mathrm{PVY}^{\mathrm{N}} \mathrm{Wi}$ or $\mathrm{PVY}^{\mathrm{NTN}}$ virus contacted with endoplasmic reticulum cistern and vesicles of ER or Golgi apparatus origin were observed in all types of the tissues (Fig. 10b-d), also in non-infected leaves (Fig. 10b, c) despite localised hypersensitive response. ER cisterns were very often characterised by a swollen structure and were filled with fibril material (Fig. 10d). An ultrastructural analysis of PVYtobacco compatible interaction demonstrated not only distinct virus particles connection to such cisterns, but also contact of these structures with cytoplasmic viral inclusions (Fig. 10d, e). Endoplasmic reticulum cistern was subject to strong labelling on epitope of PVY protein capsid, starting from 1st day after inoculation in the case of HR response (Figs. 9d, 10a). 
Fig. 3 Ultrastructural changes in cell nucleus during PVY ${ }^{\mathrm{NTN}}$ or $\mathrm{PVY}^{\mathrm{N}} \mathrm{Wi}$ infection. a Viral particles $(V P)$ connected with the enlarged complex of nucleus pore (arrow) and with ER in a spongy parenchyma cell of the potato cv. Rywal $10 \mathrm{~h}$ after $\mathrm{PVY}^{\mathrm{NTN}}$ inoculation, bar $=1 \mu \mathrm{m}$, b viral particles $(V P)$ attached to enlarged nuclear pore complexes (arrows) in tobacco cv. Samsun palisade mesophyll cell, bar $=0.5 \mu \mathrm{m}$, c expanded nuclear envelope with vesicles and perinuclear areas (arrows) during HR 1 day after PVY ${ }^{\text {NTN }}$ inoculation, bar $=1 \mu \mathrm{m}$ and d condensed chromatin in cell nucleus $(N)$ with $\mathrm{PVY}^{\mathrm{N}} \mathrm{Wi}$ cytoplasmic inclusion $(C I)$ attached to nucleus envelope 24 days after potato cv. Rywal inoculation, $b a r=0.2 \mu \mathrm{m}$
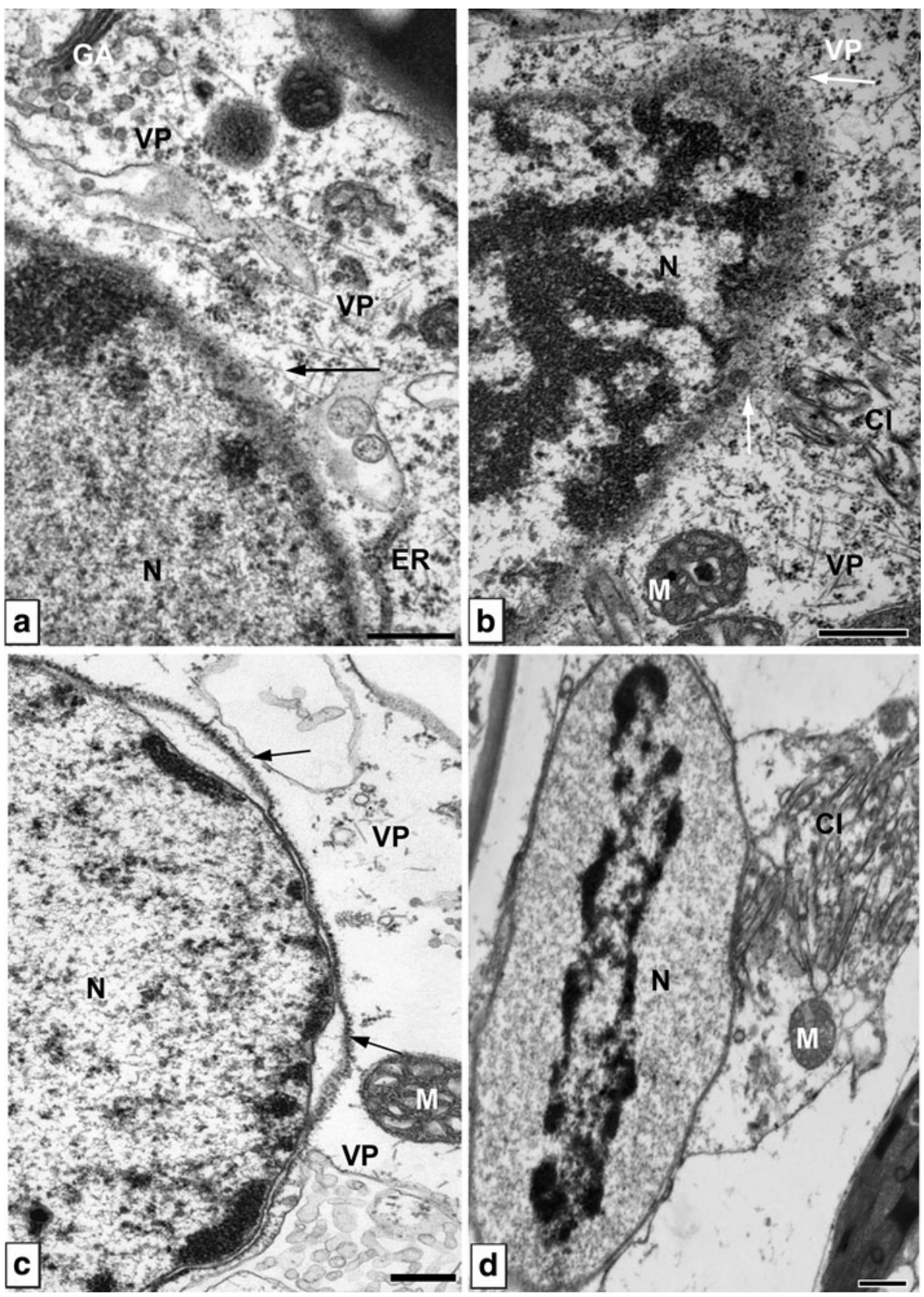

\section{Discussion}

An ultrastructural analysis of infected potato and tobacco tissues representing two types of PVY-host plant interactions demonstrated dynamic and proceeding cytopathological changes in cell organelles both on an area of mesophyll and vascular tissues. Cell nucleus is an organelle which changes prove an engagement in a response on PVY infection. The literature data concerning the studies on HR reaction with respect to cell membrane only cite the information of amoeboid nucleus shape with chromatin condensation, and they mainly concern interactions with fungal pathogen (Heath et al. 1997; Mould and Heath
1999). Modifications in nuclei have been reported in geminivirus-infected tomato. Observed features in nuclei described as areas of granulated electron dense structures and nuclear inclusions (Channarayappa et al. 1992). Also the phenomenon of nuclear blebbing characteristic for apoptosis observed as a result of Arabidopsis thalianaPseudomonas syringae interactions, was reported (Levine et al. 1996). Lobed shape of cell nucleus together with strong dilatation of nuclear envelope was observed in case of compatible and incompatible interaction of PVY with potato and tobacco plants, which resulted in formation of considerable perinuclear areas filled with fibril substance. An increase in nuclear pore complexes, clearly attached to 
Fig. 4 Potato virus $Y$ particles inside cell nucleus. a $\mathrm{PVY}^{\mathrm{N}} \mathrm{Wi}$ particles $(V P)$ inside cell nucleus $(N)$ in hypersensitive response 24 days after inoculation. Viral cytoplasmic inclusions $(C I)$ in cytoplasm around nucleus of phloem parenchyma cell. Frame indicates fragment enlarged in Fig. $3 \mathrm{~b}$, bar $=0.1 \mu \mathrm{m}$, b enlarged region from Fig. 3a, bar $=0.1 \mu \mathrm{m}, \mathbf{c} \mathrm{PVY}^{\mathrm{NTN}}$ particles $(V P)$ inside mesophyll cell nucleus $(N)$ in compatible interaction with tobacco cv. Samsun. Cytoplasmic inclusions $(C I)$ around nucleus, bar $=0.5 \mu \mathrm{m}$
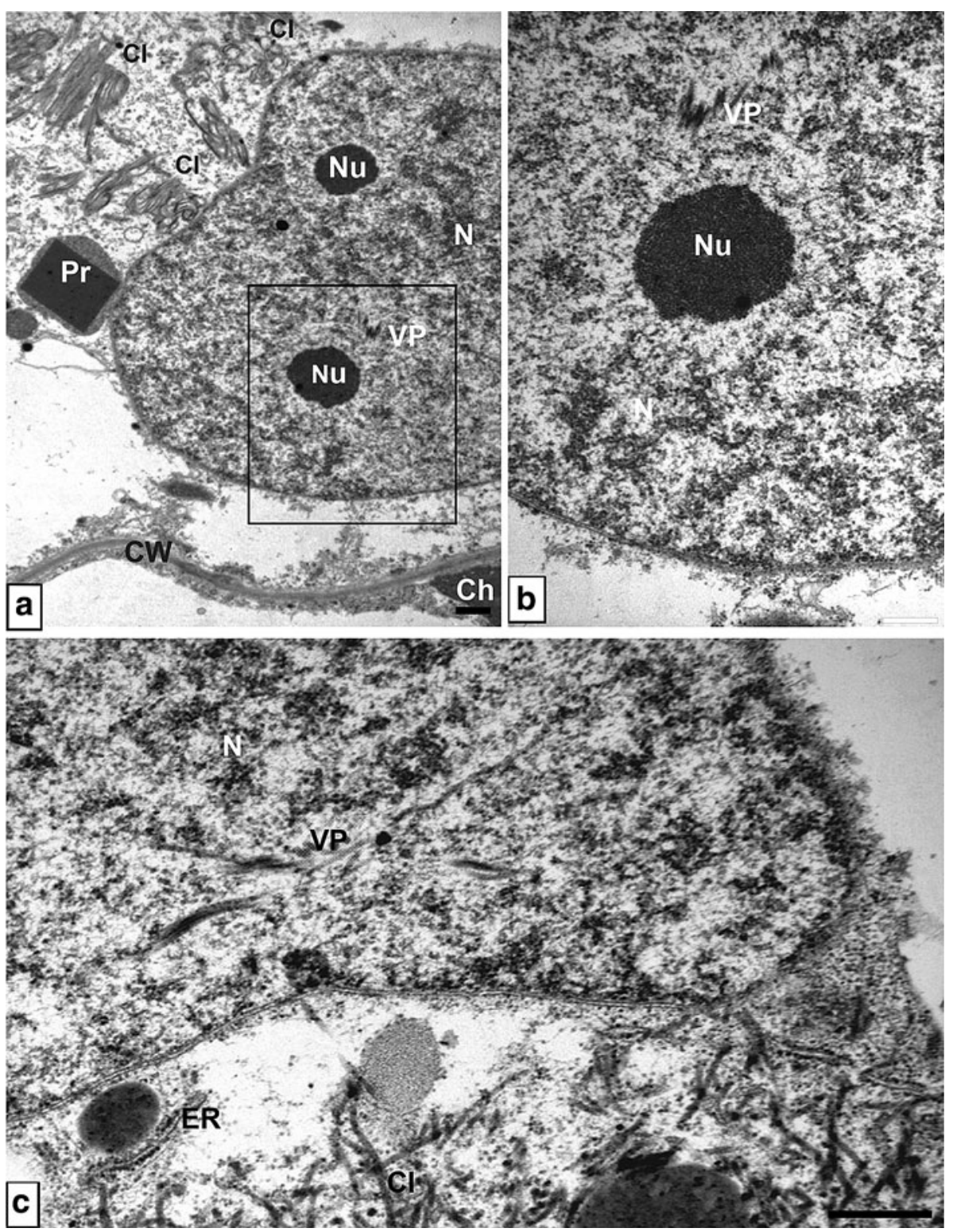

virus particles and inclusions, was reported very often. Particles transfer inside cell membrane seems to be possible taking into account nucleoproteins export and import to/from cell nucleus (Krichevsky et al. 2006). This is highly probable, since PVY particles inside the cell nucleus were observed for the first time on various infection stages, both in HR response and compatible interaction. The question of the purpose of virus particles transfer inside the nucleus of host cell stays an open issue. Significance and consequences of virus particles presence, as well as its proteins and genetic material in cell nucleus require an explanation.

Potyviruses replicate their genetic material within cytoplasm (Hong and Hunt 1996; Kopek et al. 2007; Revers et al. 1999; Riechmann et al. 1992), however the possibility of viral RNA replication in host cell nucleus cannot be excluded, since it was noted based on the study on TEV and PPV viruses that the main enzyme, i.e. RdRp replicase (NIb protein), is deposited in the nucleus in a form of aggregates and also in a form bounded to NIa and VPg (Riedel et al. 1998). Moreover, cell nucleus is engaged in the process of response on PVY virus activity, since as soon as after 1 day of inoculation some of the mentioned above changes in its structure are observed, resulting in further stages of infection in strong chromatin condensation or sometimes in cell envelope disruption. Antigen of capsid protein was localised inside the nucleus and nucleolus during an advanced infection in compatible interaction. This fact also allows supposing that also PVY particles lying may occur at nucleus area.

Also mitochondria subject to considerable cytopathological changes, both as a result of compatible and HR 
Fig. 5 Mitochondria during compatible and incompatible tobacco- or potato-PVYNTN interactions. a Virus particles $(V P)$ attached to mitochondrion $(M)$ envelope in the vicinity of cytoplasmic inclusions $(C I)$ in tobacco mesophyll cell, $b a r=1 \mu \mathrm{m}, \mathbf{b}$ expanded mitochondrion cristae forming electron-lucent areas inside these organelles $(M)$ in necrotised phloem parenchyma cell in HR, bar $=1 \mu \mathrm{m}$, $\mathbf{c}$ virus particles $(V P)$ in the cytoplasm of xylem parenchyma cells. Mitochondria exosome forming 1 day after PVY ${ }^{\mathrm{NTN}}$ potato cV. Rywal inoculation, bar $=1 \mu \mathrm{m}$ and $\mathbf{d}$ expanded mitochondria exosome and virus particles $(V P)$ in storage parenchyma cell of potato cv. Igor light sprouts, bar $=1 \mu \mathrm{m}$

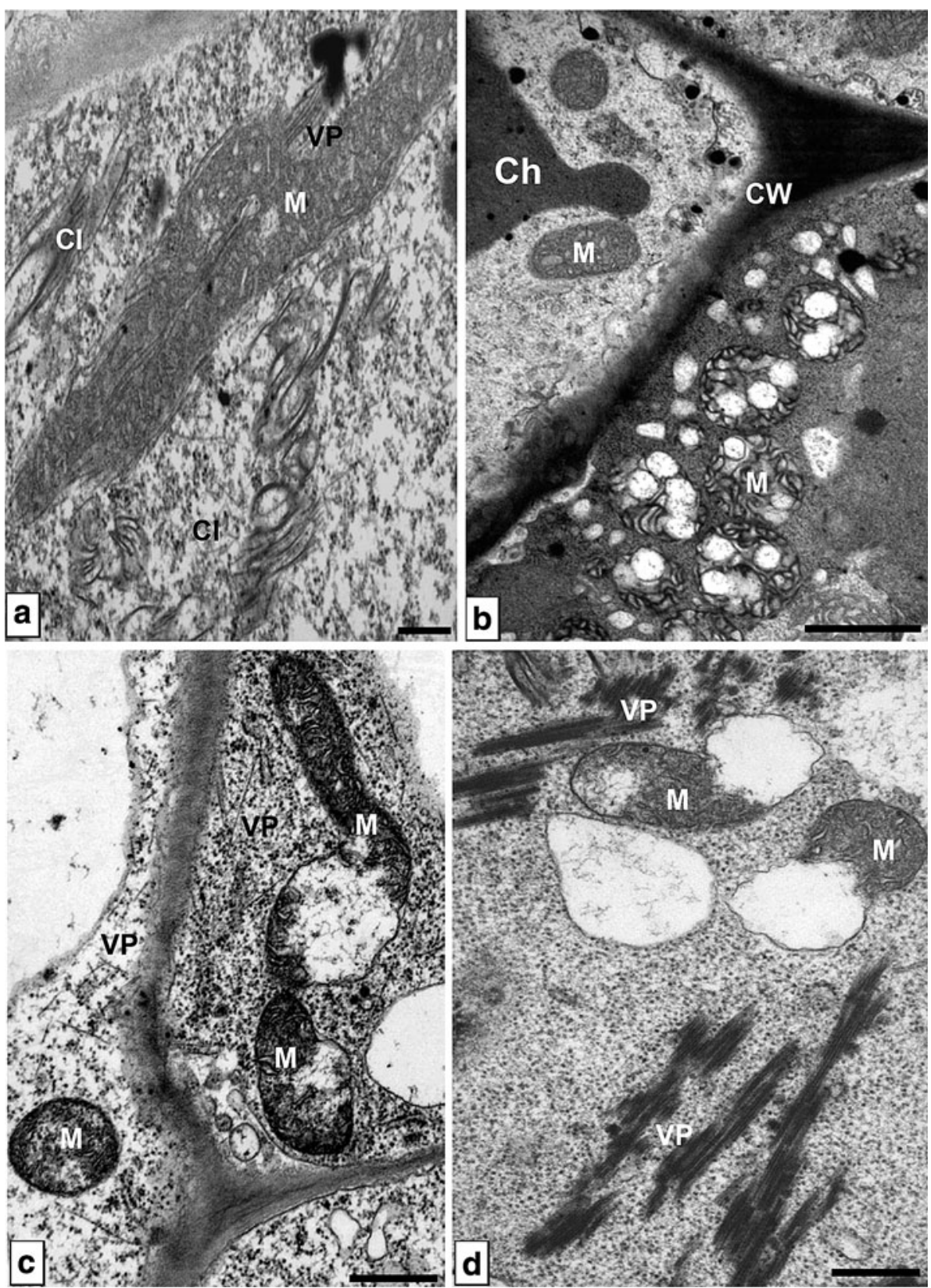

response, were engaged in PVY-tobacco or -potato interactions. Previous documented studies between $\mathrm{PVY}^{0}$ and potato cv. Quarta demonstrated only changed membranes of mitochondria and forming microbodies (Hinrichs-Berger et al. 1999). An application of transmission electron microscopy is not the method of quantitative analysis; however it may be concluded based on multiple experiment replications that the number of mitochondria considerably increased during infection compared to healthy material. Moreover, $\mathrm{PVY}^{\mathrm{N}} \mathrm{Wi}$ and $\mathrm{PVY}^{\mathrm{NTN}}$ particles attached to mitochondrial envelope were observed very often in mesophil, phloem and xylem parenchyma, both in HR response and as a result of compatible host/PVY interaction. The presence of electron-dense substance inside mitochondria and close contact of these organelles with endoplasmic reticulum and cell nucleus were demonstrated during an advanced infection in tobacco tissues as well in potato from bud test. Also formation of electron-lucent areas was observed inside mitochondria during mitochondrial cristae swelling. Moreover, formation of mitochondrial exosomes was noted in the cells of light sprouts and sometimes virus particles were found inside the mitochondria. Mitochondrial cristae enlargement as well as exosomes formation in the course of HR response in potato cv. Rywal occurred as soon as at the first day after inoculation with necrotic PVY strains, while electron-lucent areas in swollen mitochondria 
Fig. 6 Mitochondria and chloroplast changes as a result of compatible and incompatible PVY-potato and -tobacco interactions. a Virus particles $(V P)$ inside mitochondria $(M$, arrows) in storage parenchyma cell of potato cv. Igor light sprouts, $b a r=2 \mu \mathrm{m}$, b virus particles $(V P)$ inside mitochondrion $(M$, arrow) in tobacco mesophyll cell, $b a r=1 \mu \mathrm{m}$, c virus particles deforming chloroplast $(\mathrm{Ch})$ structure (frame) in potato cv. Rywal mesophyll cell. Indicated fragment enlarged in Fig. 5d, bar $=1 \mu \mathrm{m}$ and $\mathbf{d}$ enlarged frame from Fig. 5c. Virus particles $(V P$, arrows $)$ inside chloroplast $(\mathrm{Ch})$ and in cytoplasm, bar $=1 \mu \mathrm{m}$

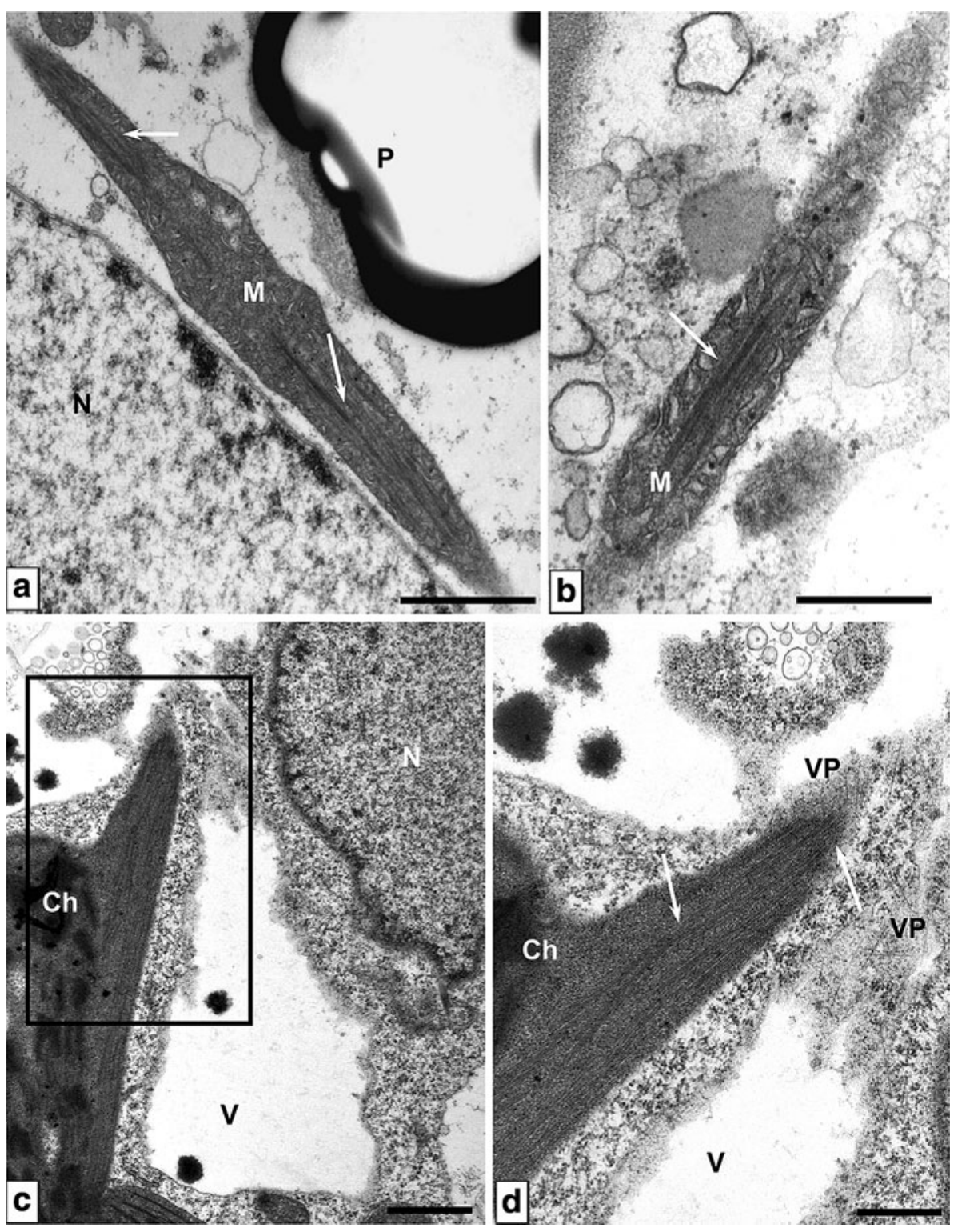

were formed starting from the third day after inoculation. Localisation of PVY capsid protein allowed noting the presence of this protein inside mitochondria (on advanced infection stages), while during HR (3 days after inoculation) PVY CP was localised in the vicinity of mitochondrial envelope. Analogical changes in mitochondria structure were observed by Selga et al. (2005) during leaf blades mesophyll programmed cell death (PCD) resulted from factitious ethylene release leading in a consequence to chromatin condensation and nucleus fragmentation (Selga and Selga 1993). Electron-lucent areas inside the mitochondria were referred as these organelles vacuolisation, leading to cristae hyper-swelling (Selga et al. 2005). The phenomenon also noted during PCD was separation of exosomes from mitochondria to cytosol. Mitochondria play an important role in $\mathrm{PCD}$, due to production of reactive oxygen species and cytochrome release, and activating proteases and nucleases they are able for cell degradation (Lam et al. 2001). During PCD the cristae have an ability of swelling, which leads to pore formation in an external envelope membrane (Tiwari et al. 2002; Yu et al. 2002). Damages in an external mitochondrial membrane and cytochrome c release to cytosol may lead to an inhibition of electron flow from complex III to IV in an internal envelope membrane. Such phenomena lead to generation of reactive oxygen species which in turn are a signal of PCD. Mitochondria play a role of numerous signals "regulator" which reflects ion homeostasis and metabolic cell status, also in PCD (Lam et al. 2001). An increased number of mitochondria in PVY infection may be related not only to high metabolic activity of the cell during PCD, but also to virus life cycle, which is demonstrated by a strict 
Fig. 7 Plastid ultrastructure changes. a Deformed chloroplasts $(\mathrm{Ch})$ with disorganised lamellas and expanded structure. Virus cytoplasmic inclusions $(C I)$ in cytoplasm of tobacco cv. Samsun mesophyll cell, bar $=0.1 \mu \mathrm{m}, \mathbf{b}$ disorganised amyloplast $(P)$ structure surrounded by viral cytoplasmic inclusions $(C I)$ in storage parenchyma cell of potato $\mathrm{cv}$. Igor light sprouts, bar $=2 \mu \mathrm{m}$, c virus particles $(V P)$ connected with chloroplast $(\mathrm{Ch})$ without envelope and with distended ER cistern in HR 1 day after PVY inoculation. Fibril material inside cistern, bar $=1 \mu \mathrm{m}$

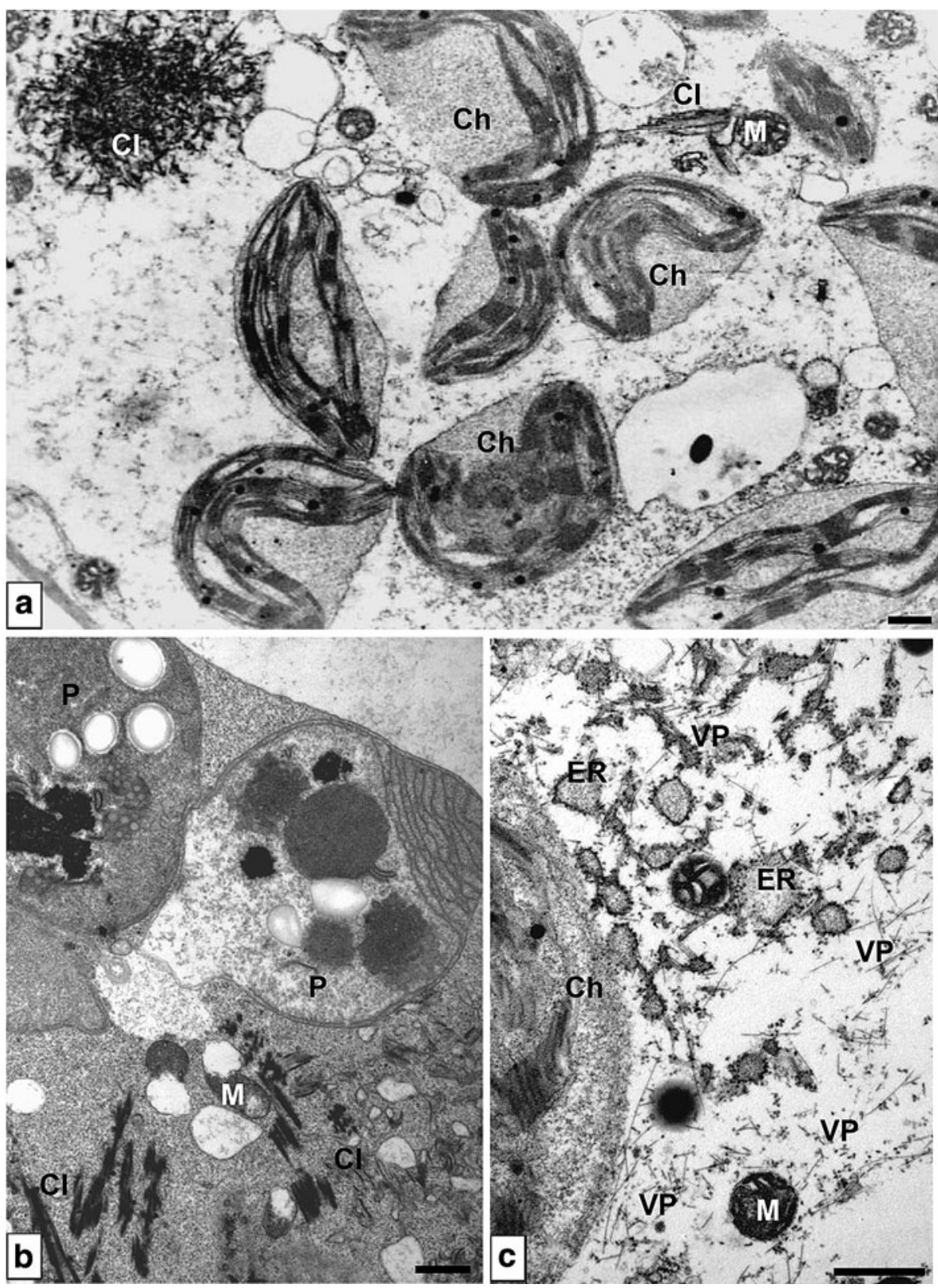

particles contact with an envelope and the presence of PVY particles inside these organelles. Also deposition of PVY in mitochondria of capsid protein in further stages of compatible interaction seems to be a significant issue. Both particles and PVY capsid protein may be removed/released to cytoplasm, presumably due to an ability of exosomes formation.

The disorders in lamellas arrangement inside the chloroplast, shape changes suggesting these organelles swelling resulted from chlorotic changes as well as complete destruction in wide necrotisation image were noted in necrotisation subjected changes both in compatible interaction and hypersensitive response. Similar observations described Almási et al. (1996) for Tomato spotted wilt virus
(TSWV) causing degenerative changes of chloroplast, such as swelling, more osmophilic globule and loosened thylakoid structure. Shape changes also caused a strong accumulation of electron-dense substances in plastid stroma (chloroplast and leucoplast) suggesting the contribution of plastid in defence response on virus activity, like in the case in HR reaction in tobacco/TMV arrangement (Mittler and Lam 1995). An increased metabolic activity of the cells was demonstrated not only in an elevated chloroplast number, but also large starch granules inside the plastids (chloroplast and amyloplast of light sprouts). Virus particles of necrotic strains attached to chloroplast envelope were observed as soon as $10 \mathrm{~h}$ and 1 day after inoculation in hypersensitive response in potato cv. Rywal. The 
Fig. 8 Chloroplast structure in hypersensitive response to $\mathrm{PVY}^{\mathrm{N}} \mathrm{Wi}$ infection.

a Chloroplast $(\mathrm{Ch})$ without envelope with disorganised lamella structures connected with viral particles $(V P) 1$ day after infection, $b a r=1 \mu \mathrm{m}$, b virus particles $(V P)$ attached to chloroplast $(\mathrm{Ch})$ in potato $\mathrm{cv}$. Rywal phloem parenchyma cell 3 days after infection. Asterisk indicates cell wall $(\mathrm{CW})$ deformation, bar $=0.5 \mu \mathrm{m}$, c viral particles $(V P)$ attached to chloroplast $(\mathrm{Ch})$ connected two organelles in palisade mesophyll cell 1 day after infection, bar $=0.5 \mu \mathrm{m}$

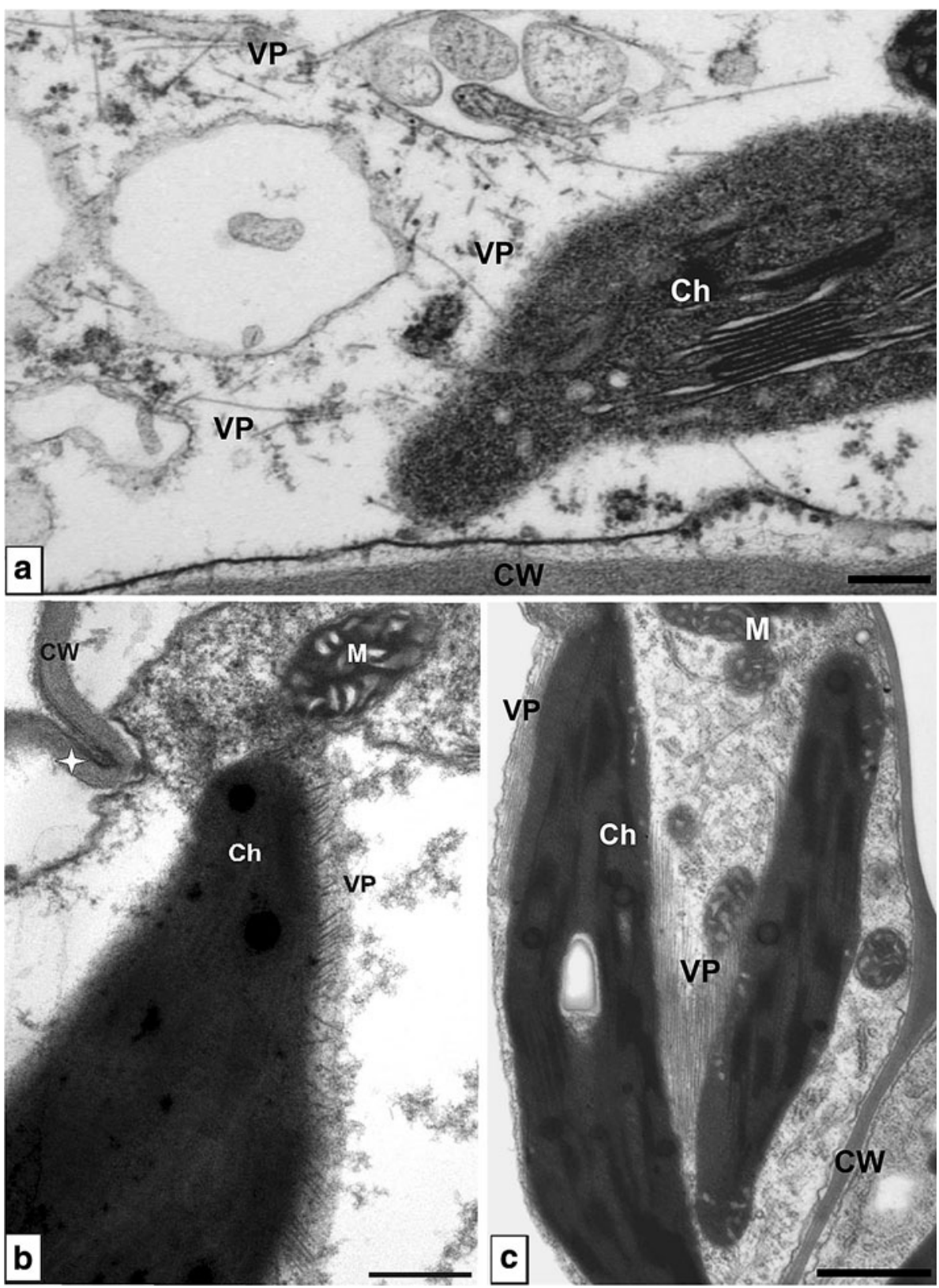

presence of chloroplast without envelope was noted in chlorotic areas 1 day after infection. Moreover, PVY particles were observed inside the chloroplast 5 days after inoculation with necrotic stains. Previous studies on compatible interaction in host/PVY arrangement did not exhibit virus particles inside the plastid, as well as attached to this organelle envelope, since they concerned only further infection stages. Goodman et al. (1986) noted already that all host/virus interactions lead to chlorotic or necrotic symptoms being a result of the changes in chloroplast structure and metabolism. Previously conducted investigations have concentrated on relations between virus infection symptoms, physiological aspects of reduced photosynthesis activity (Rahoutei et al. 2000) and also statistical quantification of chloroplast numbers and the thylakoid system (for example in ZYMV infected pumpkin plants; Zechmann et al. 2003). An analysis of interactions of some TMV strains may lead to the synthesis of capsid protein in chloroplast (Hodgson et al. 1989; Reinero and Beachy 1989). In TMV infected tobacco plants, the severity of chlorotic symptoms is correlated with the amount of viral CP (about $10.5 \%$ of all thylakoids) bound to the PS II complex inside the chloroplast (Balachandran et al. 1997). The demonstrated decrease in thylakoids in leaves of virus infected plants could have a diminishing effect on photosynthesis and could be responsible for the decrease in chlorophyll content during infection (Lohaus et al. 2000). In the case of PVY, our study did not 
Fig. 9 Immunogold labelling of PVY capsid protein. a The antigen of capsid protein located in mitochondria $(M)$ (asterisks) in the plasmodesmata $(P D)$ vicinity in tobacco mesophyll cells, bar $=0.2 \mu \mathrm{m}$, b capsid protein gold particles deposits (arrows) in cytoplasm around chloroplast $(\mathrm{Ch})$ where virus particles $(V P)$ present in potato cv. Igor mesophyll cells, bar $=0.1 \mu \mathrm{m}$. c colloidal gold particles (asterisks) in cell nucleus $(N)$ and nucleolus $(N u)$ 3 days after PVY inoculation in potato cv. Rywal mesophyll cells. Deposits also located in mitochondria $(M)$,

bar $=0.2 \mu \mathrm{m}$ and $\mathbf{d}$ colloidal gold particles strongly decorated ER cistern (arrows) and cytoplasm around ER in potato cv. Rywal mesophyll cell 1 day after $\mathrm{PVY}^{\mathrm{N}} \mathrm{Wi}$ inoculation, $b a r=0.1 \mu \mathrm{m}$
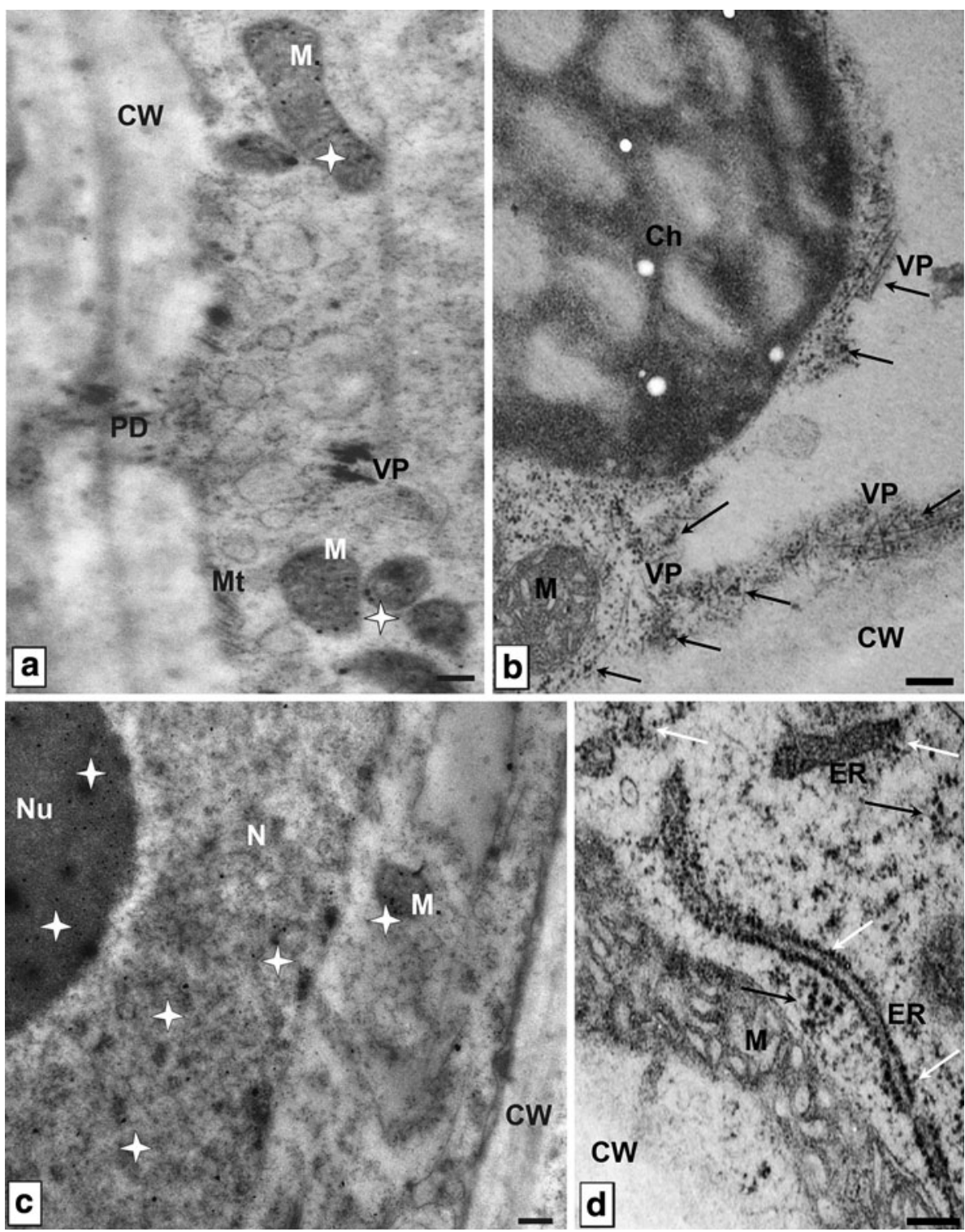

demonstrate PVY CP presence inside the chloroplast, but in cytoplasm just near to envelope with an occurrence of HR symptoms. It is probable that chloroplasts take part in the process of virus particles assembly, since capsid protein is observed just by the envelope. It may be supposed that the result of this process is observed in further stages of infection, when PVY particles are already present inside chloroplasts.

Virus particles of lower diameter attached to ER were observed starting from 10th $\mathrm{h}$ after an inoculation of potato cv. Rywal tissues with necrotic strains of PVY. The cisterns were very often characterised by swollen structure and the interior was filled with fibril material looking as nucleic acid. This occurred in the cells of mesophyll, phloem and xylem parenchyma, and even inside tracheal xylem elements. In turn, during compatible interaction, particles of necrotic strains of PVY were attached to ER cistern (in the tissues of potato cv. Igor and tobacco cv. Samsun). The above information confirms the suggestions that membranous structures, and especially ER, are a probable site of PVY potyvirus replication (Hong and Hunt 1996). It is suggested in the view of data presented and observations concerning cell nucleus and mitochondria, that ER would not be the only membranous structure being a site of replication. The question whether it is the only function player by ER during infection and interactions with necrotic PVY strains is an open issue. Strong labelling on the presence of capsid protein PVY ${ }^{\mathrm{NTN}}$ along ER cistern was noted in the tissues of potato Rywal (in HR) starting from the first day of inoculation, and in the tissues of tobacco cv. Samsun (in compatible interaction). Taking into account high specialisation of ER domains in plant cell, it is possible that the synthesis of specific proteins like pathogen capsid protein and particles laying proceeds with this organelle 


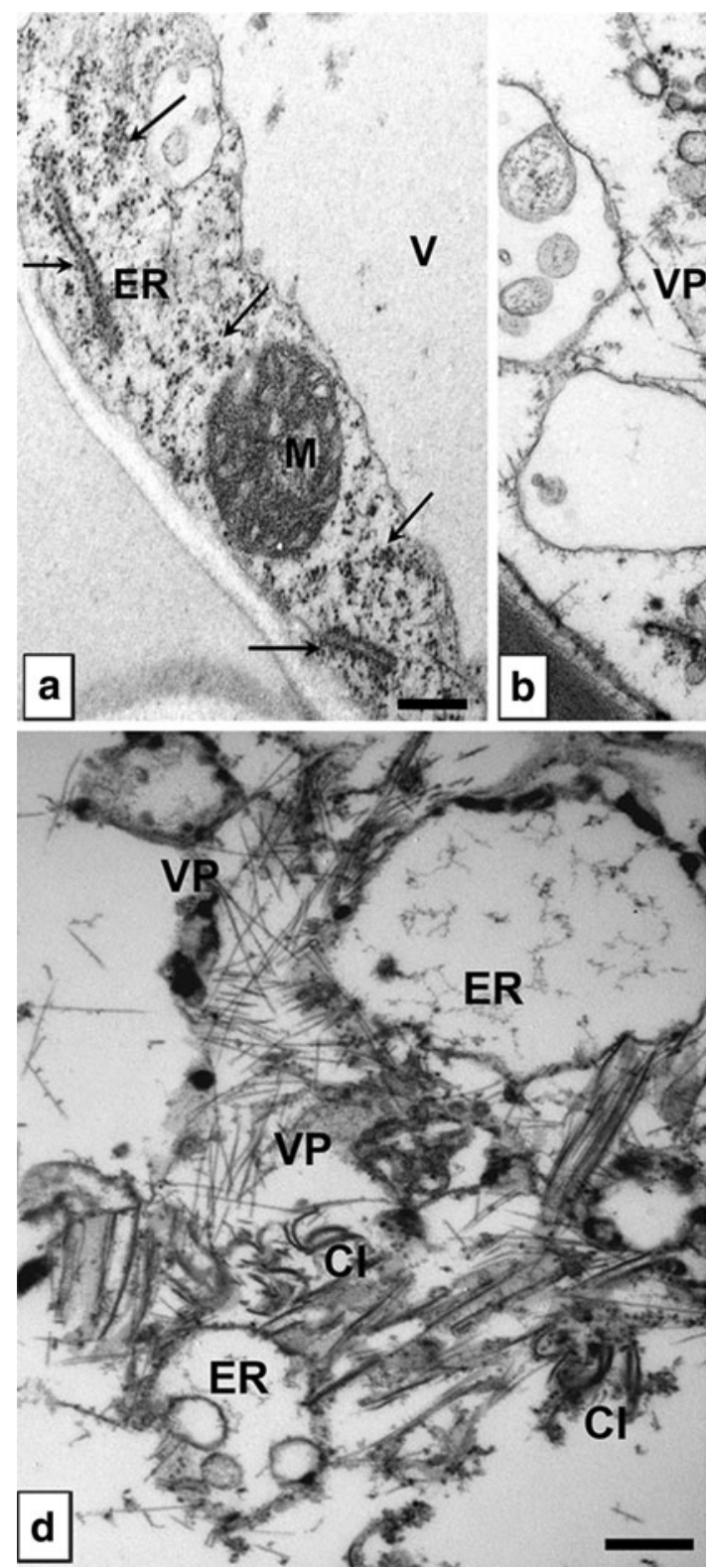

Fig. 10 Endoplasmic reticulum and Golgi apparatus in compatible and incompatible PVY- potato and -tobacco interactions. a Gold particles indicated PVY capsid protein decorated endoplasmic reticulum cistern and cytoplasm areas around ER 3 days after inoculation in phloem parenchyma cell in HR. Plants material from noninoculated leaf, bar $=0.1 \mu \mathrm{m}, \mathbf{b} \mathrm{PVY}^{\mathrm{NTN}}$ particles attached to Golgi apparatus vesicles in potato cv. Rywal phloem parenchyma cell 3 days after inoculation from noninoculated leaf, $b a r=1 \mu \mathrm{m}$, $\mathbf{c}$ virus

contribution. Depending on the virus, distinct cellular organelles, such as the endoplasmatic reticulum, are recruited for formation of the virus replication complex. Previously, $6 \mathrm{~K}$ protein of Turnip mosaic virus has been shown to be an integral membrane protein at ER. Wei et al. (2010) presented evidence that $6 \mathrm{~K}$ protein participates in vesicle induction, the target chloroplast where they induce chloroplast membrane invaginations.
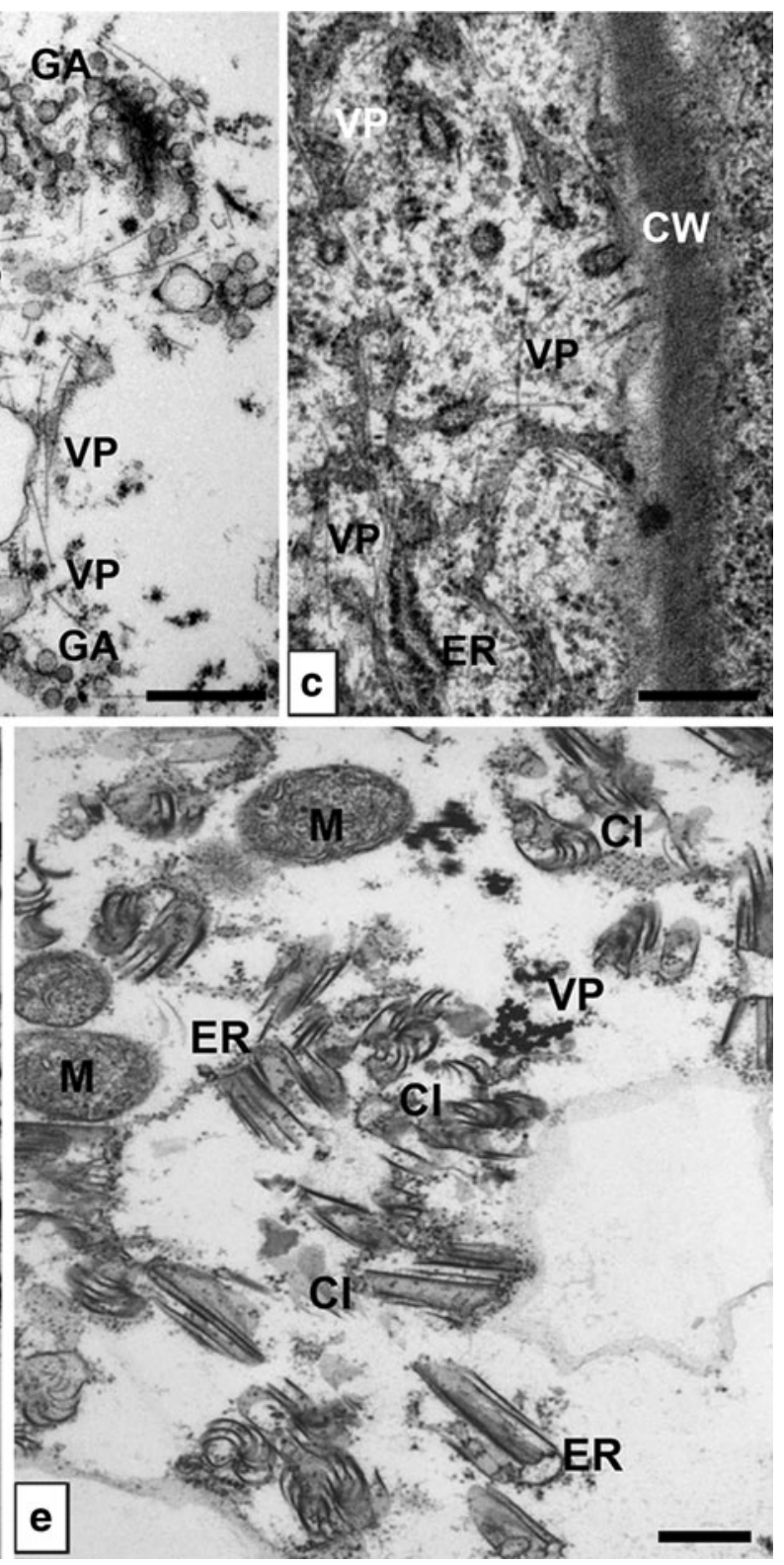

particles associated with ER cistern in xylem parenchyma cell 5 days after PVY inoculation. Section from noninoculated leaf, bar $=1 \mu \mathrm{m}$, d viral particles $(V P)$ and inclusions $(C I)$ in different condensation stages connected with distended ER cistern in phloem parenchyma tobacco cells, bar $=0.1 \mu \mathrm{m}$ and e PVY cytoplasmic inclusions $(C I)$ in different condensation stages attached to ER cistern in potato $\mathrm{cv}$. Igor mesophyll cell, bar $=0.1 \mu \mathrm{m}$

The next fact is an extremely often connection of viral cytoplasmic inclusions with ER cisterns-the most often of laminar type (never amorphous ones in potato and tobacco tissues, entirely with light sprouts). This situation concerns both observations in HR and compatible interactions. The above data suggests that vesicle structures are probably engaged in synthesis and/or sorting of the proteins of cytoplasmic inclusions of PVY virus. 
Specialisation of ER domains in plant tissue may be regulated by development stage, environment al conditions, but what import ant also by stress conditions like protection against pathogen activity. Subcellular structures which are formed from plant ER may play various functions. They are surrounded with single membrane of ER cisterns origin, and have also an ability of synthesis and compartments of specific, unique proteins for which the target site may be vacuole, other membranous structures and also apoplast. This kind of vesicles are a form of endoplasmic reticulum bodies (Galili 2004; Staehelin 1997), which are a site of transport of the proteins of cytoplasmic PVY inclusions, synthesised in ER since ER bodies' development often occurs as a response on stress conditions. Formation of these structures is a form of existence strategy and cell protection in stress conditions (Hara-Nishimura et al. 2005). Highly dynamic organellesecreted proteins undergo multiple processing steps, which are supervised and conducted by the ER quality control system (ER-QC). Notably, processing of secreted proteins can be considerably elevated under stress conditions and exceed ER folding capacities. The resulting accumulation of unfolded proteins is defined as ER-stress. The efficiency of the cell store establishes proper ER function and is crucial for stress adaptation. Besides delivering antagonistic proteins directly and resolving stress conditions, the ER monitors synthesis of immune receptors (Hüttner and Strasser 2012). This indicates the significance of the ER for the establishment and function of the plant immune system. Induction of the ER-QC machinery accompanies synthesis of immunity-associated proteins in plants (Jelitto-Van Dooren et al. 1999; Wang et al. 2005). Consequently, ER-QC mutants are more susceptible to ER stress inducers and pathogens ( $\mathrm{Li}$ et al. 2009; Saijo et al. 2009; Wang et al. 2005). Recent studies point out the fragility of the entire system and highlight the ER as an initiator of PCD in plants, as has been reported for vertebrates.

Author contribution K. Otulak designed and carried out the experiments, analysed data and wrote the manuscript. G. Garbaczewska analysed data and made suggestions to the manuscript.

Acknowledgment The authors would like to thank inż. Ewa Znojek for ultramicrotomy work.

Conflict of interest The authors declare that they have no conflict of interest.

Open Access This article is distributed under the terms of the Creative Commons Attribution License which permits any use, distribution, and reproduction in any medium, provided the original author(s) and the source are credited.

\section{References}

Almási A, Gáborjányi R, Ekés M (1996) Ultrastructural changes of tobacco plants in different compatible host-parasite relations. Acta Phytopathol Entomol Hung 31:181-190

Balachandran S, Hurry VM, Kelley SE, Osmond CB, Robinson SA, Rohozinski J, Seaton GGR, Sims DA (1997) Concepts of plant biotic stress. Some insights into the stress physiology of virusinfected plants, from the perspective of photosynthesis. Physiol Plant 100:203-212

Beczner L, Horvath J, Romhanyi I, Forster H (1984) Studies on the etiology of tuber necrotic ringspot disease in potato. Potato Res 27:339-352

Channarayappa Muniyappa V, Schwegler-Berry D, Shivashankar G (1992) Ultrastructural changes in tomato infected with tomato leaf curl virus, a whitefly-transmitted geminivirus. Can J Bot 70:1747-1753

Chrzanowska M (1991) New isolates of the necrotic strain of potato virus $\mathrm{Y}\left(\mathrm{PVY}{ }^{\mathrm{N}}\right.$ ) found recently in Poland. Potato Res 34:179-182

Chrzanowska M (1994) Differentiation of potato virus Y (PVY) isolates. Phytopathol Pol 8:15-20

Chrzanowska M, Doroszewska T (1997) Comparison between PVY isolates obtained from potato and tobacco plants grown in Poland. Phytopathol Polon 8:15-20

Chung BY, Miller WJ, Atkins JF, Firth AE (2008) An overlapping essential gene in the Potyviridae. Proc Natl Acad Sci USA 105:5897-5902

Clark MF, Adams AN (1977) Characteristics of the microplate method of enzyme-linked immunosorbent assay for the detection of plant viruses. J Gen Virol 34:475-483

Fauquet CM, Mayo MA, Maniloff J, Desselberger U, Ball LA (eds) (2005) Virus taxonomy. In: Eight report of the ICTV. Elsevier Academic Press, London

Galili G (2004) ER-derived compartments are formed by highly regulated processes and have special functions in plants. Plant Physiol 136:3411-3413

Goodman RN, Kiraly Z, Wood KR (1986) Photosynthesis. The biochemistry and physiology of plant disease. University Missouri Press, Columbia

Hara-Nishimura I, Hatsugai N, Nakaune S, Kuroyanagi M, Nishimura M (2005) Vacuolar processing enzyme: an executor of plant cell death. Curr Opin Plant Biol 8:404-408

Heath MC, Nimchuk ZL, Xu H (1997) Plant nuclear migrations as indications of critical interactions between resistant and susceptible cowpea epidermal cells and invasion hyphae of the cowpea rust fungus. New Phytol 135:689-700

Hinrichs- Berger J, Harold M, Berger S, Buchenauer H (1999) Cytological responses of susceptible and extremely resistant potato plants to inoculation with potato virus Y. Physiol Mol Plant Pathol 55:143-150

Hodgson RAJ, Beachy RN, Pakrasi HB (1989) Selective inhibition of photosystem II in spinach by tobacco mosaic virus: an effect of the viral coat protein. FEBS Lett 245:267-270

Hong Y, Hunt AG (1996) RNA polymerase activity catalyzed by a potyvirus-encoded RNA-dependent RNA polymerase. Virology 226:146-151

Hüttner S, Strasser R (2012) Endoplasmic reticulum-associated degradation of glycoproteins in plants. Front Plant Sci 3:67. doi: 10.3389/fpls.2012.00067

Jelitto-Van Dooren EP, Vidal S, Denecke J (1999) Anticipating endoplasmic reticulum stress. A novel early response before pathogenesis related gene induction. Plant Cell 11:19351944 
Karnovsky MJ (1965) A formaldehyde-glutaraldehyde fixative of high osmolarity for use in electron microscopy. J Cell Biol 27:137A

Kerlan C, Le Romancer M (1992) In: Ritter E, Perez de San Roman C (compilers) Proceedings of the 11th EAPR virology section meeting, Vitoria-Gasteiz, pp 77-80, 29 June-3 July 1992

Kopek BG, Perkins G, Miller DJ, Ellisman MH, Ahlquist P (2007) Three-dimensional analysis of a viral RNA replication complex reveals a virus-induced mini-organelle. PLoS Biol 5:e220. doi:10.1371/journal.pbio.0050220

Krichevsky A, Kozlovsky SV, Gafni Y, Citovsky V (2006) Nuclear import and export of plant virus proteins and genomes. Mol Plant Pathol 7:131-146

Lam E, Kato N, Lawton M (2001) Programmed cell death, mitochondria and the plant hypersensitive response. Nature 411:848-853

Levine A, Pennell RI, Alvarez ME, Palmer R, Lamb C (1996) Calcium mediated apoptosis in plant hypersensitive disease resistance response. Curr Biol 6:427-437

Li J, Zhao-Hui C, Batoux M, Nekrasov V, Roux M, Chinchilla D, Zipfel C, Jones JD (2009) Specific ER quality control components required for biogenesis of the plant innate immune receptor EFR. Proc Natl Acad Sci USA 106:15973-15978

Lohaus G, Heldt HW, Osmond CB (2000) Infection with phloem limited abutilon mosaic virus causes localized carbohydrate accumulation in leaves of Abutilon striatum: relationships to symptom development and effects on chlorophyll fluorescence quenching during photosynthetic induction. Plant Biol 2:161167

McCartney AW, Greenwood JS, Fabian MR, White KA, Mullen RT (2005) Localization of the tomato bushy stunt virus replication protein p33 reveals a peroxisome-to-endoplasmic reticulum sorting pathway. Plant Cell 17:3513-3531

Mittler R, Lam E (1995) Identification, characterization, and purification of a tobacco endonuclease activity induced upon hypersensitive response cell death. Plant Cell 7:1951-1962

Mould MJR, Heath MC (1999) Ultrastructural evidence of differential changes in transcription, translation and cortical microtubule during in planta penetration of cells resistant and susceptible to rust infection. Physiol Mol Plant Pathol 55:225-236

Otulak K, Garbaczewska G (2010) Ultrastructural events during hypersensitive response of potato cv. Rywal infected with necrotic strains of potato virus Y. Acta Physiol Plantarum 32:635-644

Otulak K, Garbaczewska G (2012) Cytopathological potato virus Y structures during Solanaceous plants infection. Micron 43:839850

Prod'homme D, Le Panse S, Drugeon G, Jupin I (2001) Detection and subcellular localization of the Turnip yellow mosaic virus $66 \mathrm{~K}$ replication protein in infected cells. Virology 281:88-101

Rahoutei J, Garcia-Luque I, Baron M (2000) Inhibition of photosynthesis by viral infection: effect on PSII structure and function. Physiol Plant 110:286-292

Reinero A, Beachy RN (1989) Reduced photosystem II activity and accumulation of viral coat protein in chloroplasts of leaves infected with tobacco mosaic virus. Plant Physiol 89:111-116

Revers F, Le Gall O, Candresse T, Maule AJ (1999) New advances in understanding the molecular biology of plant/potyvirus interactions. Mol Plant Microbe Interact 12:367-376
Riechmann L, Lain S, Garcia JA (1992) Highlights and prospects of potyvirus molecular biology. J Gen Virol 73:1-16

Riedel D, Lesemann DE, Maiss E (1998) Ultrastructural localization of nonstructural and coat proteins of 19 potyviruses using antisera to bacterially expressed proteins of plum pox potyvirus. Arch Virol 143:2133-2158

Robert Y, Woodford JAT, Ducray-Bourdin DG (2000) Some epidemiological approaches to the control of aphid-borne virus diseases in seed potato crops in northern Europe. Virus Res 71:33-47

Saijo Y, Tintor N, Lu X, Rauf P, Pajerowska-Mukhtar K, Häweker H, Dong X, Robatzek S, Schulze-Lefert P (2009) Receptor quality control in the endoplasmic reticulum for plant innate immunity. EMBO J 28:3439-3449

Selga T, Selga M (1993) Effect of ethylene producer camposan M on the genome and morphogenesis of plants. Proc Latv Acad Sci B12:71-73

Selga T, Selga M, Pavila V (2005) Death of mitochondria during programmed cell death of leaf mesophyll cells. Cell Biol Int 29:1050-1056

Shalitin D, Wolf S (2000) Cucumber mosaic virus infection affects sugar transport in melon plants. Plant Physiol 123:597-604

Staehelin LA (1997) The plant ER: a dynamic organelle composed of a large number of discrete functional domains. Plant J 11:11511165

Szajko K, Chrzanowska M, Witek K, Strzelczyk-Zyta D, Zagórska H, Gebhardt C, Hennig J, Marczewski W (2008) The novel gene $\mathrm{Ny}-1$ on potato chromosome IX confers hypersensitive resistance to potato virus $\mathrm{Y}$ and is an alternative to Ry genes in potato breeding for PVY resistance. Theor Appl Genet 116:297-303

Tiwari BS, Belenghi B, Levine A (2002) Oxidative stress increases respiration and generation of reactive oxygen species, resulting in ATP depletion, opening of mitochondria permeability transition and programmed cell death. Plant Physiol 128:1271-1281

Urcuqui-Inchima S, Haenni AL, Bernardi F (2001) Potyvirus proteins: a wealth of functions. Virus Res 74:157-175

Valkonen JPT (2007) Viruses: economical losses and biotechnological potential. In: Vreugdenhil D, Bradshaw J, Gebhardt C, Govers F, Taylor M, MacKerron D, Ross H (eds) Potato biology and biotechnology: advances and perspectives. Elsevier, Amsterdam, pp 619-641

van Lent WM, Verduin BJM (1986) Detection of viral protein and particles in thin section of infected plant tissue using immunogold labeling. Dev Appl Biol 1:193-211

Wang D, Weaver ND, Kesarwani M, Dong X (2005) Induction of protein secretory pathway is required for systemic acquired resistance. Science 308:1036-1040

Wei T, Zhang C, Hong J, Xiong R, Kasschau KD et al (2010) Formation of complexes at plasmodesmata for potyvirus intercellular movement is mediated by the viral protein P3NPIPO. PLoS Pathog 6:e1000962. doi:10.1371/journal.ppat.1000962

Yu F, Finley RL, Raz A, Kim HRC (2002) Galectin-3 translocates to the perinuclear membranes and inhibits cytochrome $\mathrm{c}$ release from the mitochondria A role for synexin in galectin-3 translocation. J Biol Chem 277:15819-15827

Zechmann B, Muller M, Zellnig G (2003) Cytological modifications in zucchini yellow mosaic virus (ZYMV)-infected Styrian pumpkin plants. Arch Virol 148:1119-1133 